\title{
SELECTION OF EXTRACURRICULAR ACTIVITIES IN SMK INSAN AQILAH 4 JAKARTA USING PROFILE MATCHING METHOD
}

\author{
Wahyudin'1, Andi Saryoko², Abdul Aziz ${ }^{3}$, Lia Nurmalia ${ }^{4}$ \\ 1Program Studi Administrasi Bisnis, Fakultas Ekonomi \& Bisnis \\ Universitas Bina Sarana Informatika \\ www.bsi.ac.id \\ wahyudin.whd@bsi.ac.id

\begin{abstract}
${ }^{2}$ Program Studi Teknik Informatika; ${ }^{3}$ Program Studi Sistem Informasi Sekolah Tinggi Manajemen Informatika dan Komputer Nusa Mandiri www.nusamandiri.ac.id

andi.asy@nusamandiri.ac.id, abdaziz081@gmail.com
\end{abstract} \\ ${ }^{4}$ Program Studi Bahasa Inggris, Fakultas Komunikasi \& Bahasa \\ Universitas Bina Sarana Informatika \\ www.bsi.ac.id \\ lia.lnm@bsi.ac.id
}

\begin{abstract}
This research is based on the observations and experiences of researchers, because the many extracurricular activities in schools make it difficult for students to determine extracurricular activities that can develop their personality, talents, and abilities outside the academic field, therefore the system is created to select extracurricular activities. The aim is to help students deal with extracurricular selection problems. The application of the Profile Matching method in the decision support system for the selection of extracurricular activities is expected to help provide recommendations for extracurricular activities to overcome the problem of selecting extracurricular activities and can facilitate students in selecting extracurricular activities.
\end{abstract}

Keywords: Extracurricular, SMK, Profile Matching

Abstrak-Penelitian ini didasarkan pada
pengamatan dan pengalaman para peneliti, karena
banyaknya kegiatan ekstrakurikuler di sekolah
menyulitkan siswa untuk menentukan kegiatan
ekstrakurikuler yang dapat mengembangkan
kepribadian, bakat, dan kemampuan mereka di luar
bidang akademik, oleh karena itu sistem dibuat
untuk memilih kegiatan ekstrakurikuler. Tujuannya
adalah untuk membantu siswa menangani masalah
pemilihan ekstrakurikuler. Penerapan metode
Profile Matching dalam sistem pendukung
keputusan untuk pemilihan kegiatan
ekstrakurikuler diharapkan dapat membantu
memberikan rekomendasi kegiatan ekstrakurikuler
untuk mengatasi masalah pemilihan kegiatan
ekstrakurikuler dan dapat memfasilitasi siswa
dalam memilih kegiatan ekstrakurikuler.

Kata kunci: ekstrakurikuler, SMK, Profile Matching INTRODUCTION

In Indonesia, extracurricular activities are not new thing. Because it is already exists start from the basic education level to the college level, so that everyone knows it very well.

The formulation of an extracurricular definition is also contained in the DECREE of Dirjen Dikdasmen number 226/C/KEP 1992 (Saputra, 2017) states that extracurricular activities are beyond regular tuition hours and during school holidays performed both at school and outside the school, with the aim of deepening students ' knowledge, identifying relationships between lessons, channeling talents and interests, and complementing the full human development efforts (Hastuti, 2008).

At this time, every school is obliged to carry out extracurricular activities. These extracurricular activities are expected to help students to grow independently. In this case, through these activities, it is possible to direct and foster the interests, talents and potential of the students who are involved in improving their achievement in both talent and academic. (Inriyani, 2017)

This research was conducted in SMK INSAN AQILAH 4 Jakarta. There are 4 extracurricular options, namely film, Silat, OSIS and theater. These options make the students confused in choosing extracurricular activities that are appropriate to their interests and talents. So they need a system of decision makers. However, in this research the researchers focus only on the art category they are film and theater.

This decision-making process is assisted by a decision support system. Through this system is 
expected that students can precisely choose the extracurricular according to their interests and expertise. This system is used to help decisionmaking in half-structured situations and unstructured situations, where no one knows exactly how the decision should be made (Sugiyono, 2018).

The researchers hope that every student at SMK INSAN AQILAH 4 JAKARTA find interest and talent in one of the extracurricular in SMK INSAN AQILAH 4 JAKARTA. Based on the problems that occur, it can be identified that students still confused choosing extracurucular (Hoiri \& Agustina, 2014) especially, film and theater extracurricular, it can be seen from the number of students who move from one extracurricular to another (Wisnawati, 2016), This may be due to the absence of an extracurricular decision-making system in the school. (Hoiri \& Agustina, 2014)

The purpose of this research is to provide solutions to the problems of film and theater extracurricular elections to students. Hopefully, there is an increasing number of students who follow extracurricular according to their interests and talents. It is also able to apply and build a decision making model using the method of profile matching (Indriyani, 2019) In the extracurricular elections based on pre-determined criteria.

\section{MATERIALS AND METHODS}

\section{Stages of research}

In this study each satges of research is described in detail as follows:

\section{Preliminary study}

At this stage, the researchers conducted a field studies and literature studies. The study of literature in this case is used to determine the theory and method used in the method of problem solving of the Profile Matching method. While field studies are conducted to learn how the method that is running related to the research object in SMK INSAN AQILAH 4 Jakarta.

2. Formulation of problems

The formulation of the problem resulted from the analysis of researchers at the time of field studies and data taken from the interview with the administration and section extracurricular sections of SMK INSAN AQILAH 4 Jakarta. The result of the formulation of this problem is also used as purpose in the research.

\section{Data Collection and Data processing}

In the third stage, the unification of data is required as a material used to provide alternaïve solutions that have been formulated in the second stage. Once data is made one, the processing of data will be used in the analysis stage. In the process of analysis will be examined the data.

\section{Analysis}

At this stage there is analysis process and ranking of the results of the problem discussion using the Profile Matching method. In general the discussion of the issue contains the calculation stage of existing data, using a valid formula of Profile Matching method. Each stage will be discussed thoroughly according to the steps already in the Profile Matching method. The result of this problem is expected to provide an alternative calculation of better in determining the extracurricular activities of students at SMK INSAN AQILAH 4 Jakarta.

\section{Conclusion}

At this stage, researchers concluded the results of research that has been implemented on the basis of data processing results using the Profile Matching method. This conclusion is a statement taken from the calculations produced by the research method.

\section{Suggestion}

As the next step of the conclusion, the researcher formulated the advice related to the ongoing process of the research object in order to provide beneficial results in the future.

\section{Research Instruments}

Research instrument is a mechanism used in data collection or information that is useful to produce solutions to the research problem. Instruments as a tool at the time of research using a method of research instruments consists of the following:

1. Kuantitatif Data

The Data gathered from the questionnaire results using mathematical calculation techniques through Microsoft Excel.

\section{Questionnaire}

This questionnaire was given to students of grade X pharmaceuticals at SMK INSAN AQILAH 4 Jakarta, with a total of 16 respondents. Questionnaires and questionnaire questions were determined by the questions.

\section{Data Collection Methods}

In the preparation of this research need a certain method that will be used in the collection of data obtained in the following manner:

a. Interview

The data collection method is to conduct a direct question-and-answer with an extracurricular contractor.

b. Library Studies

The Library study method is to find the appropriate data by reading the books of scientific 
works that correspond to the subject of both text book and internet articles.

c. Questionnaire

In this technique the respondents were given the opportunity to fill a poll with the answers already available. Thus, the answer is closed.

\section{Population and Research samples}

a) Population

The population of this research is the student/I grade 10 pharmacy SMK INSAN AQILAH 4 Jakarta. Based on data in May 2019, the number of students in Grade 10 pharmacy in SMK INSAN AQILAH 4 Jakarta amounted to 20 students.

b) Research Sample

In determining the sample, researchers use purposive sampling techniques and Slovin formulas, purposive sampling is the determination of the sample on the basis of specific aspects and criteria in this study.

\section{Data Analysis Methods}

In this profile matching process is needed input from the art aspect and the aspect of the attitude obtained from the questionnaire that has been filled by the respondent.

1. Firstly, Explaining the criteria that will be made as a problem resolution standard.

Table 1 Criteria Description Value

\begin{tabular}{cllc}
\hline No & Aspect & Criteria & $\begin{array}{c}\text { Question } \\
\text { number }\end{array}$ \\
\hline \multirow{2}{*}{1} & \multirow{2}{*}{ Seni } & Film & $1-5$ \\
\cline { 3 - 4 } & & Teater & $6-10$ \\
\hline \multirow{3}{*}{2} & \multirow{2}{*}{ Sikap } & Percaya Diri & 11 \\
\cline { 3 - 4 } & & Adaptasi & 12 \\
\cline { 3 - 3 } & & Inisiatif & 13 \\
\cline { 3 - 4 } & & Kedisiplinan & 14 \\
\cline { 3 - 4 } & & Pengetahuan & 15 \\
\hline
\end{tabular}

Source: (Wahyudin, Saryoko, \& Aziz, 2019)

Table 2 Valuation Scale

\begin{tabular}{ll}
\hline \multirow{3}{*}{ Sub Criteria Value } & Very agree $=5$ \\
\cline { 2 - 2 } & Agree $=4$ \\
\hline & Hesitant $=3$ \\
\hline Disagree $=2$ \\
\hline
\end{tabular}

Source: (Wahyudin et al., 2019)

2. Calculating GAP values between the subject profile and the required profile.

Table 3 GAP calculation

\begin{tabular}{cccl}
\hline No & Difference & Value & \multicolumn{1}{c}{ Description } \\
\hline 1 & 0 & 5 & No Gap \\
\hline 2 & 1 & 4.5 & Individual competency \\
\hline
\end{tabular}

\begin{tabular}{cccl}
\hline 3 & -1 & 4 & $\begin{array}{l}\text { Individual competence less } \\
\text { 1 level }\end{array}$ \\
\hline 4 & 2 & 3.5 & $\begin{array}{l}\text { Individual competency } \\
\text { Excess 2 levels }\end{array}$ \\
\hline 5 & -2 & 3 & $\begin{array}{l}\text { Individual competence less } \\
\text { 2 levels }\end{array}$ \\
\hline 6 & 3 & 2.5 & $\begin{array}{l}\text { Individual competence } \\
\text { Excess 3 levels }\end{array}$ \\
\hline 7 & -3 & 2 & $\begin{array}{l}\text { Individual competence less } \\
3 \text { levels }\end{array}$ \\
\hline 8 & 4 & 1.5 & $\begin{array}{l}\text { Individual competence } \\
\text { Excess 3 levels }\end{array}$ \\
\hline 9 & -4 & 1 & $\begin{array}{l}\text { Individual competence less } \\
\text { 4 levels }\end{array}$ \\
\hline 10 & 5 & 0 & $\begin{array}{l}\text { Individual Competencies } \\
\text { Pros 5 levels }\end{array}$ \\
\hline
\end{tabular}

Source: (Adhar, 2014)

3. Compute GAP Mapping value sourced from GAP analysis.

The formula of calculating the average value Core Factor dan Secondary Factor sebagai berikut:

$N C F=\Sigma N C \Sigma I C$

$N S F=\Sigma N S \Sigma I S$

Description:

NCF: Average Factor Value

NSF: Average Secondary Factor Score

NC: Total Number of Core Factor Values

IC: Total Number of Core Factor Item Values

NS: Total Number of Secondary Factor Values

IS: Total Number of Secondary Factor Item Values

4. Calculate the final value

After finishing the core factor and secondary factor calculation, the next step is to perform the calculation of the final or total value based on the percentage of core factor and secondary factor that is thought to be influential. The formula for the extracurricular determination is as follows:

$(\mathrm{X}) \% \mathrm{x} \mathrm{NCF}+(\mathrm{X}) \% \mathrm{x} \mathrm{NSF}=\mathrm{N}$

Description:

NCF: The average value of the core factor

NSF: The average value of secondary factor

$N$ : The total value of aspects of the study

(X)\%: Percent Value inputed

\section{Conducting a step}

After the process of calculating the final value of all aspects of art and attitudes, the next stage is determining the ranking stage. Where this stage is the final stage of profile matching.

\section{RESULTS AND DISCUSSION}

From the calculation results of each of the above specifications then recalculated the total value based on the presentation of the core and 
secondary that is expected to affect the performance of each profile. To be more accurate in the process of calculating the data, then for each calculation of the total value of the first specified percentage value that will be in input is core factor $60 \%$ and secondary factor $40 \%$. Then the core factor and secondary factor values will be calculated according to the formula and the result can be seen in the calculation example of art aspect and attitude aspect as the example below:

Table 4. Calculating the total value of art aspects

\begin{tabular}{|c|c|c|c|c|c|c|}
\hline \multirow[b]{2}{*}{ No } & \multirow[b]{2}{*}{ Name } & \multirow[b]{2}{*}{$\mathrm{NCF}$} & \multirow[b]{2}{*}{ NSF } & \multicolumn{2}{|c|}{ Total Score } & \multirow{2}{*}{$\frac{\mathrm{N} 1}{\mathrm{~N} 1=\mathrm{NCF}+\mathrm{NSF}}$} \\
\hline & & & & $\begin{array}{l}60 \% \\
{ }^{*} \mathrm{NCF}\end{array}$ & $\begin{array}{c}40 \% \\
* \\
\text { NSF }\end{array}$ & \\
\hline 1 & $\begin{array}{l}\text { Adelia Putri } \\
\text { Oktaviani }\end{array}$ & 4.5 & 3.5 & 2.7 & 1.4 & 4.1 \\
\hline 2 & $\begin{array}{l}\text { Aulia Dwi } \\
\text { Cahyani }\end{array}$ & 4.5 & 2.5 & 2.7 & 1 & 3.7 \\
\hline 3 & $\begin{array}{l}\text { Dhea } \\
\text { Muthia } \\
\text { Putri }\end{array}$ & 4.5 & 3.5 & 2.7 & 1.4 & 4.1 \\
\hline 4 & Diana Fitria & 3 & 4.5 & 1.8 & 1.8 & 3.6 \\
\hline 5 & $\begin{array}{l}\text { Farinda } \\
\text { Anggrainie }\end{array}$ & 5 & 4.5 & 3 & 1.8 & 4.8 \\
\hline 6 & $\begin{array}{l}\text { Fatahillah } \\
\text { Olyvan }\end{array}$ & 3 & 2.5 & 1.8 & 1 & 2.8 \\
\hline 7 & $\begin{array}{l}\text { Geger } \\
\text { Ramadhan }\end{array}$ & 4.5 & 4 & 2.7 & 1.6 & 4.3 \\
\hline 8 & $\begin{array}{l}\text { Hasbie } \\
\text { Abdillah } \\
\end{array}$ & 4.5 & 5 & 2.7 & 2 & 4.7 \\
\hline 9 & $\begin{array}{l}\text { Indriyani } \\
\text { Novita Sari }\end{array}$ & 4 & 4.5 & 2.4 & 1.8 & 4.2 \\
\hline 10 & $\begin{array}{l}\text { Mutia } \\
\text { Lamatenggo }\end{array}$ & 4.5 & 4.5 & 2.7 & 1.8 & 4.8 \\
\hline 11 & $\begin{array}{l}\text { Mutiara } \\
\text { Maheswari }\end{array}$ & 5 & 3.5 & 3 & 1.4 & 4.4 \\
\hline 12 & Nina Susana & 5 & 4.5 & 3 & 1.8 & 4.8 \\
\hline 13 & $\begin{array}{l}\text { Putri } \\
\text { Puspitasari }\end{array}$ & 4 & 3.5 & 2.4 & 1.4 & 3.8 \\
\hline 14 & $\begin{array}{l}\text { Retno } \\
\text { Pertiwi }\end{array}$ & 5 & 4.5 & 3 & 1.8 & 4.8 \\
\hline 15 & $\begin{array}{l}\text { Sahrul } \\
\text { Afriyan } \\
\text { Nurzaqi }\end{array}$ & 4.5 & 4.5 & 2.7 & 1.8 & 4.5 \\
\hline 16 & $\begin{array}{l}\text { Sagita } \\
\text { Wulan Ayu } \\
\text { Puspitasari }\end{array}$ & 4 & 4.5 & 2.4 & 1.8 & 4.2 \\
\hline
\end{tabular}

Table 5. Total Attitude Value Calculation

\begin{tabular}{|c|c|c|c|c|c|c|}
\hline \multirow[b]{2}{*}{ No } & \multirow[b]{2}{*}{ Name } & \multirow[b]{2}{*}{ NCF } & \multirow[b]{2}{*}{ NSF } & \multicolumn{2}{|c|}{ Total Score } & \multirow{2}{*}{$\begin{array}{c}\mathrm{N} 2 \\
\mathrm{~N} 2=\mathrm{NCF}+\mathrm{NS} \\
\mathrm{F}\end{array}$} \\
\hline & & & & $\begin{array}{c}60 \% \\
{ }^{*} \mathrm{NC} \\
\mathrm{F}\end{array}$ & $\begin{array}{c}40 \\
\% * \\
\text { NSF }\end{array}$ & \\
\hline 1 & $\begin{array}{l}\text { Adelia Putri } \\
\text { Oktaviani }\end{array}$ & 4.5 & 3 & 2.7 & 1.2 & 3.9 \\
\hline 2 & $\begin{array}{l}\text { Aulia Dwi } \\
\text { Cahyani }\end{array}$ & $\begin{array}{c}3.83 \\
3\end{array}$ & 3.5 & 2.2 & 1.4 & 3.6 \\
\hline 3 & $\begin{array}{l}\text { Dhea } \\
\text { Muthia } \\
\text { Putri }\end{array}$ & 4.5 & 3 & 2.7 & 1.2 & 3.9 \\
\hline 4 & Diana Fitria & 4.5 & 4 & 2.7 & 1.6 & 4.3 \\
\hline 5 & $\begin{array}{l}\text { Farinda } \\
\text { Anggrainie }\end{array}$ & 4.5 & 3.5 & 2.7 & 1.4 & 4.1 \\
\hline 6 & $\begin{array}{l}\text { Fatahillah } \\
\text { Olyvan }\end{array}$ & 4.5 & 4 & 2.7 & 1.6 & 4.3 \\
\hline
\end{tabular}

\begin{tabular}{|c|c|c|c|c|c|c|}
\hline \multirow[b]{2}{*}{ No } & \multirow[b]{2}{*}{ Name } & \multirow[b]{2}{*}{ NCF } & \multirow[b]{2}{*}{ NSF } & \multicolumn{2}{|c|}{ Total Score } & \multirow{2}{*}{$\begin{array}{c}\mathrm{N} 2 \\
\mathrm{~N} 2=\mathrm{NCF}+\mathrm{NS} \\
\mathrm{F}\end{array}$} \\
\hline & & & & $\begin{array}{c}60 \% \\
{ }^{*} \mathrm{NC} \\
\mathrm{F}\end{array}$ & $\begin{array}{c}40 \\
\% * \\
\text { NSF }\end{array}$ & \\
\hline 7 & $\begin{array}{l}\text { Geger } \\
\text { Ramadhan }\end{array}$ & 4.5 & $\begin{array}{c}4.7 \\
5 \\
\end{array}$ & 2.7 & 1.9 & 4.6 \\
\hline 8 & $\begin{array}{l}\text { Hasbie } \\
\text { Abdillah }\end{array}$ & 5 & 4.5 & 3 & 1.8 & 4.8 \\
\hline 9 & $\begin{array}{l}\text { Indriyani } \\
\text { Novita Sari }\end{array}$ & 4.5 & 4 & 2.7 & 1.6 & 4.3 \\
\hline $\begin{array}{l}1 \\
0\end{array}$ & $\begin{array}{l}\text { Mutia } \\
\text { Lamatengg } \\
\text { o }\end{array}$ & $\begin{array}{c}4.66 \\
7\end{array}$ & 4.5 & 2.8 & 1.8 & 4.6 \\
\hline $\begin{array}{l}1 \\
1\end{array}$ & $\begin{array}{l}\text { Mutiara } \\
\text { Maheswari }\end{array}$ & 4.5 & 3.5 & 2.7 & 1.4 & 4.1 \\
\hline $\begin{array}{l}1 \\
2\end{array}$ & $\begin{array}{l}\text { Nina } \\
\text { Susana }\end{array}$ & 3.5 & 2.5 & 2.1 & 1 & 3.1 \\
\hline $\begin{array}{l}1 \\
3 \\
\end{array}$ & $\begin{array}{l}\text { Putri } \\
\text { Puspitasari }\end{array}$ & 4.5 & 4 & 2.7 & 1.6 & 4.3 \\
\hline $\begin{array}{l}1 \\
4\end{array}$ & $\begin{array}{l}\text { Retno } \\
\text { Pertiwi }\end{array}$ & $\begin{array}{c}4.66 \\
7\end{array}$ & 3.5 & 2.8 & 1.4 & 4.2 \\
\hline $\begin{array}{l}1 \\
5\end{array}$ & $\begin{array}{l}\text { Sahrul } \\
\text { Afriyan } \\
\text { Nurzaqi }\end{array}$ & 4.5 & 4 & 2.7 & 1.6 & 4.3 \\
\hline $\begin{array}{l}1 \\
6\end{array}$ & $\begin{array}{l}\text { Sagita } \\
\text { Wulan Ayu } \\
\text { Puspitasari }\end{array}$ & $\begin{array}{c}4.83 \\
3\end{array}$ & 3.5 & 2.9 & 1.4 & 4.3 \\
\hline
\end{tabular}

Source: (Wahyudin et al., 2019)

\section{Calculation of rank determination}

The final outcome of this process is the rank of the Ectrakurukuler elections. Ranking of rankings refers to specific calculation results.

Here is the final result table and the determination of the extracurricular selection ranking based on the profile matching method: Here is the final result table and the determination of the selection of extracurricular activities:

Table 6. Calculation of rank determination

\begin{tabular}{|c|c|c|c|c|c|c|}
\hline \multirow{3}{*}{ No } & \multirow{3}{*}{ Name } & \multirow{3}{*}{ NCF } & \multirow{3}{*}{ NSF } & \multicolumn{2}{|c|}{ Total Score } & \multirow{3}{*}{$\frac{\mathrm{N} 1}{\mathrm{~N} 1=\mathrm{NCF}+\mathrm{NSF}}$} \\
\hline & & & & $\begin{array}{r}60 \% \\
* \mathrm{NCF}\end{array}$ & $\begin{array}{c}40 \% \\
*\end{array}$ & \\
\hline & & & & & NSF & \\
\hline \multirow[t]{2}{*}{1} & Adelia Putri & 4.1 & 3.9 & 2.46 & 1.56 & 4.02 \\
\hline & Oktaviani & & & & & \\
\hline \multirow[t]{2}{*}{2} & Aulia Dwi & 3.7 & 3.6 & 2.22 & 1.44 & 3.66 \\
\hline & Cahyani & & & & & \\
\hline \multirow[t]{2}{*}{3} & Dhea Muthia & 4.1 & 3.9 & 2.46 & 1.56 & 4.02 \\
\hline & Putri & & & & & \\
\hline 4 & Diana Fitria & 3.6 & 4.3 & 2.16 & 1.72 & 3.88 \\
\hline \multirow[t]{2}{*}{5} & Farinda & 4.8 & 4.1 & 2.88 & 1.64 & 4.52 \\
\hline & Anggrainie & & & & & \\
\hline \multirow[t]{2}{*}{6} & Fatahillah & 2.8 & 4.3 & 1.58 & 1.72 & 3.4 \\
\hline & Olyvan & & & & & \\
\hline \multirow[t]{2}{*}{7} & Geger & 4.3 & 4.6 & 2.58 & 1.84 & 4.42 \\
\hline & Ramadhan & & & & & \\
\hline \multirow[t]{2}{*}{8} & Hasbie & 4.7 & 4.8 & 2.82 & 1.92 & 4.74 \\
\hline & Abdillah & & & & & \\
\hline \multirow[t]{2}{*}{9} & Indriyani & 4.2 & 4.3 & 2.52 & 1.72 & 4.24 \\
\hline & Novita Sari & & & & & \\
\hline \multirow[t]{2}{*}{10} & Mutia & 4.8 & 4.6 & 2.88 & 1.84 & 4.72 \\
\hline & Lamatenggo & & & & & \\
\hline \multirow[t]{2}{*}{11} & Mutiara & 4.4 & 4.1 & 2.64 & 1.64 & 4.28 \\
\hline & Maheswari & & & & & \\
\hline 12 & Nina Susana & 4.8 & 3.1 & 2.88 & 1.24 & 4.12 \\
\hline \multirow[t]{2}{*}{13} & Putri & 3.8 & 4.3 & 2.28 & 1.72 & 4 \\
\hline & Puspitasari & & & & & \\
\hline 14 & Retno & 4.8 & 4.2 & 2.88 & 1.68 & 4.56 \\
\hline
\end{tabular}




\begin{tabular}{|c|c|c|c|c|c|c|}
\hline \multirow[b]{2}{*}{ No } & \multirow[b]{2}{*}{ Name } & \multirow[b]{2}{*}{$\mathrm{NCF}$} & \multirow[b]{2}{*}{ NSF } & \multicolumn{2}{|c|}{ Total Score } & \multirow{2}{*}{$\frac{\mathrm{N} 1}{\mathrm{~N} 1=\mathrm{NCF}+\mathrm{NSF}}$} \\
\hline & & & & $\begin{array}{l}60 \% \\
{ }^{*} \mathrm{NCF}\end{array}$ & $\begin{array}{c}40 \% \\
* \\
\text { NSF }\end{array}$ & \\
\hline & Pertiwi & & & & & \\
\hline 15 & $\begin{array}{l}\text { Sahrul } \\
\text { Afriyan } \\
\text { Nurzaqi }\end{array}$ & 4.5 & 4.3 & 2.70 & 1.72 & 4.42 \\
\hline 16 & $\begin{array}{l}\text { Sagita } \\
\text { Wulan Ayu } \\
\text { Puspitasari }\end{array}$ & 4.2 & 4.3 & 2.52 & 1.72 & 4.24 \\
\hline
\end{tabular}

Table 7. Method-based ranking results Profile Matching

\begin{tabular}{llll}
\hline No & \multicolumn{1}{c}{ Name } & $\begin{array}{c}\text { The } \\
\text { final } \\
\text { result }\end{array}$ & Ranking \\
\hline 1 & Hasbie Abdillah & 4.74 & 1 \\
\hline 2 & Mutia Lamatenggo & 4.72 & 2 \\
\hline 3 & Retno Pertiwi & 4.56 & 3 \\
\hline 4 & Farinda Anggrainie & 4.52 & 4 \\
\hline 5 & Geger Ramadhan & 4.42 & 5 \\
\hline 6 & Sahrul Afriyan Nurzaqi & 4.42 & 6 \\
\hline 7 & Mutiara Maheswari & 4.28 & 7 \\
\hline 8 & Indriyani Novita Sari & 4.24 & 1 \\
\hline 9 & Sagita Wulan Ayu & 4.24 & 2 \\
\hline 10 & Puspitasari & & \\
\hline 11 & Nina Susana & 4.12 & 3 \\
\hline 12 & Dhelia Putri Oktaviani & 4.02 & 4 \\
\hline 13 & Putri Puspitasari & 4.02 & 5 \\
\hline 14 & Diana Fitria & 4 & 6 \\
\hline 15 & Aulia Dwi Cahyani & 3.88 & 7 \\
\hline 16 & Fatahillah Olyvan & 3.66 & 8 \\
\hline Source (Wahy & 3.4 & 9 \\
\hline
\end{tabular}

Source: (Wahyudin et al., 2019)

From the table above it can be concluded that the students rank 1 to 7 admission to the co-curricular Fim with a value of $>4.25$ and to rank 8 to 16 entry into the extracurricular theatre with a value of $<$ 4.25 .

\section{CONCLUSION}

Based on the results of the selection of extracurricular activities in SMK INSAN AQILAH 4 Jakarta using Profile Matching method, it can be taken some conclusions as follows. First, the profile matching method can make good decisions in the screening and calculation of the values of the criteria that students have, so that students/I can choose between film and theater extracurricular. Secondly, this decision support system can be used as a foundation to determine the extracurricular students of SMK INSAN AQILAH 4 Jakarta Objectively, so that students become more educated in achieving the highest achievement that is in accordance with the potential owned, so that the students are not move around in choosing the ectrapricular. Thirdly, with the decision support system, the extracurricular of the students of SMK INSAN AQILAH 4 Jakarta become more objective. The advice of research that has been done to the party of SMK INSAN AQILAH 4 Jakarta, among others. The addition of extracurricular category for more complete. Develop the system by adding other methods in order to provide more accurate results for an extracurricular election decision support system. The extracurricular election decision support system can be developed into a web-based or desktop decision support system so that decision makers can save time calculations. The research is still using manual calculations, in the future this system can be developed using a calculation application. For example SPSS and so on.

\section{REFERENCE}

Adhar, D. (2014). Sistem Pendukung Keputusan Pengangkatan Jabatan Karyawan pada PT . Ayn dengan Metode Profile Matching. Jurnal Teknik Informatika Dan Sistem Informasi, 1(1), 16-29.

Hastuti, T. A. (2008). Kontribusi Ekstrakurikuler Bolabasket Terhadap Pembimbitan Atlet dan Peningkatan Kesegaran Jasmani. Pendidikan Jasmani Indonesia, 5(1), 45-50.

Hoiri, A., \& Agustina, R. (2014). Sistem Pakar Penentuan Jenis Ekstrakurikuler Siswa dengan Metode Forward Chaining di Sdn Bandungrejosari 1 Sukun Malang. Bimasakti.

Indriyani, F. (2019). PENERAPAN METODE PROFILE MATCHING SEBAGAI PENDUKUNG KEPUTUSAN PEMILIHAN JURUSAN PADA SMK AL HIDAYAH. Jurnal Riset Informatika, 1(2), $35-40$. https://doi.org/10.34288/jri.v1i2.31

Inriyani, Y. (2017). Pengaruh kegiatan ekstrakurikuler terhadap prestasi belajar ips melalui motivasi belajar. Jurnal Pendidikan: Teori, Penelitian, Dan Pengembangan Volume: 2 Nomor: 7 Bulan Juli Tahun 2017 Halaman: 955-962, 955-962.

Saputra, W. (2017). EFEK MENGIKUTI EKTRAKURIKULER OLAHRAGA DAN TINGKAT KEBUGARAN JASMANI TERHADAP PEMBENTUKAN SELF-ESTEEM SISWA DI SEKOLAH MENENGAH KEJURUAN (SMK). Didaktik: Jurnal Ilmiah PGSD STKIP Subang, 3(1), 126-145. https://doi.org/10.36989/didaktik.v3i1.59 
Sugiyono. (2018). METODE PENELITIA KUANTITATIF, KUALITATIF, DAN R\&D (28th ed.). Bandung: Alafabeta.

Wahyudin, W., Saryoko, A., \& Aziz, A. (2019). Laporan Penelitian Dosen Yayasan: Pemilihan Kegiatan Ekstrakurikuler Pada SMK Insan
Aqilah 4 Jakarta Menggunakan Metode Profile Matching. Jakarta.

Wisnawati, R. D. (2016). Pengelolaan Kegiatan Ekstrakurikuler Berbasis Fullday School Di SDIT Mta Gemolong. Universitas Muhammadiyah Surakarta. 